Article

\title{
Lepidium graminifolium L.: Glucosinolate Profile and Antiproliferative Potential of Volatile Isolates
}

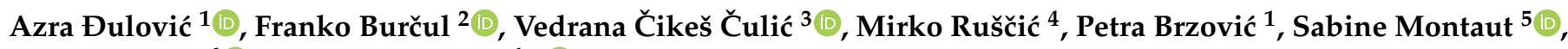 \\ Patrick Rollin ${ }^{6}$ (i) and Ivica Blažević ${ }^{1, *(1)}$
}

1 Department of Organic Chemistry, Faculty of Chemistry and Technology, University of Split, Ruđera Boškovića 35, 21000 Split, Croatia; azra@ktf-split.hr (A.Đ.); pbrzovic@ktf-split.hr (P.B.)

2 Department of Analytical Chemistry, Faculty of Chemistry and Technology, University of Split, Ruđera Boškovića 35, 21000 Split, Croatia; franko@ktf-split.hr

3 School of Medicine, University of Split, Šoltanska 2, 21000 Split, Croatia; vedrana.cikes.culic@mefst.hr

4 Department of Biology, Faculty of Science, University of Split, Ruđera Boškovića 33, 21000 Split, Croatia; mrus@pmfst.hr

5 Biomolecular Sciences Programme, School of Biological, Chemical and Forensic Sciences, Laurentian University, 935 Ramsey Lake Road, Sudbury, ON P3E 2C6, Canada; smontaut@laurentian.ca

6 Institut de Chimie Organique et Analytique, Université d'Orléans et CNRS, UMR 7311, 45000 Orléans, France; patrick.rollin@univ-orleans.fr

* Correspondence: blazevic@ktf-split.hr; Tel.: +385-21-329-434

check for updates

Citation: Đulović, A.; Burčul, F.; Čulić, V.Č.; Ruščić, M.; Brzović, P.; Montaut, S.; Rollin, P.; Blažević, I. Lepidium graminifolium $\mathrm{L}$.: Glucosinolate Profile and Antiproliferative Potential of Volatile Isolates. Molecules 2021, 26, 5183. https://doi.org/10.3390/ molecules 26175183

Academic Editor: Filomena Conforti

Received: 27 July 2021

Accepted: 23 August 2021

Published: 27 August 2021

Publisher's Note: MDPI stays neutral with regard to jurisdictional claims in published maps and institutional affiliations.

Copyright: (c) 2021 by the authors. Licensee MDPI, Basel, Switzerland. This article is an open access article distributed under the terms and conditions of the Creative Commons Attribution (CC BY) license (https:/ / creativecommons.org/licenses/by/ $4.0 /)$.

\begin{abstract}
Glucosinolates (GSLs) from Lepidium graminifolium L. were analyzed qualitatively and quantitatively by their desulfo-counterparts using UHPLC-DAD-MS/MS technique and by their volatile breakdown products-isothiocyanates (ITCs) using GC-MS analysis. Thirteen GSLs were identified with arylaliphatic as the major ones in the following order: 3-hydroxybenzyl GSL (glucolepigramin, 7), benzyl GSL (glucotropaeolin, 9), 3,4,5-trimethoxybenzyl GSL (11), 3-methoxybenzyl GSL (glucolimnanthin, 12), 4-hydroxy-3,5-dimethoxybenzyl GSL (3,5-dimethoxysinalbin, 8), 4-hydroxybenzyl GSL (glucosinalbin, 6), 3,4-dimethoxybenzyl GSL (10) and 2-phenylethyl GSL (gluconasturtiin, 13). GSL breakdown products obtained by hydrodistillation (HD) and $\mathrm{CH}_{2} \mathrm{Cl}_{2}$ extraction after hydrolysis by myrosinase for $24 \mathrm{~h}$ (EXT) as well as benzyl ITC were tested for their cytotoxic activity using MTT assay. Generally, EXT showed noticeable antiproliferative activity against human bladder cancer cell line UM-UC-3 and human glioblastoma cell line LN229, and can be considered as moderately active, while $\mathrm{IC}_{50}$ of benzyl ITC was $12.3 \mu \mathrm{g} / \mathrm{mL}$, which can be considered as highly active.
\end{abstract}

Keywords: Lepidium graminifolium L.; glucosinolates; desulfoglucosinolates; 3,4,5-trimethoxybenzyl glucosinolate; benzyl isothiocyanate; antiproliferative activity

\section{Introduction}

Glucosinolates (GSLs) are sulfur- and nitrogen-containing plant secondary metabolites that can be divided into three classes based on the structure of different amino acid precursors: aliphatic GSLs derived from methionine, isoleucine, leucine or valine, arylaliphatic GSLs derived from phenylalanine or tyrosine, and indole GSLs derived from tryptophan. A recent review in the field of GSLs revealed that only 88 of 137 GSLs found in the plant kingdom were fully characterized by modern spectroscopy techniques up to mid-2018 [1]. More recently, two new GSLs were fully characterized, $4^{\prime}-O-\beta-D-$ apiofuranosyl-3-hydroxybenzyl GSL (4'-O- $\beta$-D-apiofuranosylglucomatronalin), isolated from Hesperis laciniata All. and from Hesperis matronalis L. (Brassicaceae) [2] and 2"-O( $\alpha$-L-arabinopyranosyloxy)benzylglucosinolate (glucoochradenin) from the desert plant Ochradenus baccatus Delile (Resedaceae) [3]. An intriguing aspect of this diversity is the recurrence of GSLs derived from glucotropaeolin (benzyl GSL) in wild and cultivated plants such as several species of Hornungia, Lepidium, Pentadiplandra, Reseda, Sinapis, Tropaeolum, and Moringa, which are all characterized by quite different biological activities [4-7]. 
These activities are usually correlated to the presence of isothiocyanates (ITCs), but under certain conditions, those can show instability [8]. De Nicola et al. reported that in hydrodistillation-mimicking conditions, most benzylic-type ITCs underwent conversion into the corresponding benzyl alcohols or benzylamines [9].

The genus Lepidium (Brassicaceae family) comprises ca. 230 species among which seven are known to be wild-growing in Croatia [10,11]. Lepidium graminifolium (grassleaf pepperweed) is a perennial plant widely distributed throughout the Mediterranean region and Middle Europe. It has erect glabrous or sparsely hairy stems up to $50 \mathrm{~cm}$, branched above with small lanceolate leaves, white flowers clustered at the apex, glabrous, ovateelliptic, scarcely winged fruits and wingless and elliptic seeds [11]. It flowers from May to October. An earlier study by Friis and Kjaer showed the presence of 3-hydroxybenzyl GSL (7) and 3-methoxybenzyl GSL (12) [12]. Subsequently, analysis of hydrolysis products by GC-MS, the presence of benzyl GSL (9), 3-methylsulfanylpropyl GSL [13], 7, 12, 4hydroxybenzyl GSL (6), 3,4-dimethoxybenzyl GSL (10), and 3,4,5-trimethoxybenzyl GSL (11) was reported [14]. Indol-3-ylmethyl GSL, 4-methoxyindol-3-ylmethyl GSL, and 1methoxyindol-3-ylmethyl GSL were also detected by HPLC analysis of seedlings [15]. A systematic qualitative investigation of the GSL profile of L. graminifolium wild-growing in Croatia was performed using LC-MS of intact GSLs, and the major GSL, 7, was isolated and characterized using spectroscopic techniques [16]. The presence of 6, 9, 12 and 4methoxyindol-3-ylmethyl GSL was confirmed, while the presence of $(2 R)$-hydroxybut3-enyl GSL (1), (2S)-hydroxybut-3-enyl GSL (3), but-3-enyl GSL (4), and 2-phenylethyl GSL (13) was reported for the first time [16]. However, all previous reports provided no information on the GSL quantity in L. graminifolium, especially important due to the presence of non-ubiquitous substituted benzylic-type GSLs.

Thus, the aim of the present work was GSL quantification in different plant parts of wild-growing L. graminifolium. GSLs were identified and quantified by their desulfocounterparts using UHPLC-DAD-MS/MS. The identification of the present GSLs was also performed using GC-MS of the volatiles produced after hydrodistillation and extraction after hydrolysis by myrosinase. Furthermore, the antiproliferative activity of L. graminifolium volatiles and benzyl ITC was investigated using the MTT method against human bladder cancer cell line UM-UC-3 and human glioblastoma cell line LN229.

\section{Results and Discussion}

\subsection{Glucosinolates and Volatile Constituents}

GSLs of L. graminifolium were qualitatively and quantitatively analyzed using UHPLCDAD-MS/MS by their desulfo-counterparts (Table 1, Figures 1, S1 and S2). The qualitative analysis of GSLs was also confirmed by their breakdown products obtained through enzymatic and/or thermal degradation. Isothiocyanates (ITCs), nitriles and other volatiles originating from GSL degradation were identified by GC-MS. (Table 2).

In total, thirteen GSLs were detected by UHPLC-DAD-MS/MS analyses. The structures of the corresponding GSLs are shown in Figure 1. 
Table 1. Glucosinolate (GSL) content in L. graminifolium diverse plant parts, collected from different locations.

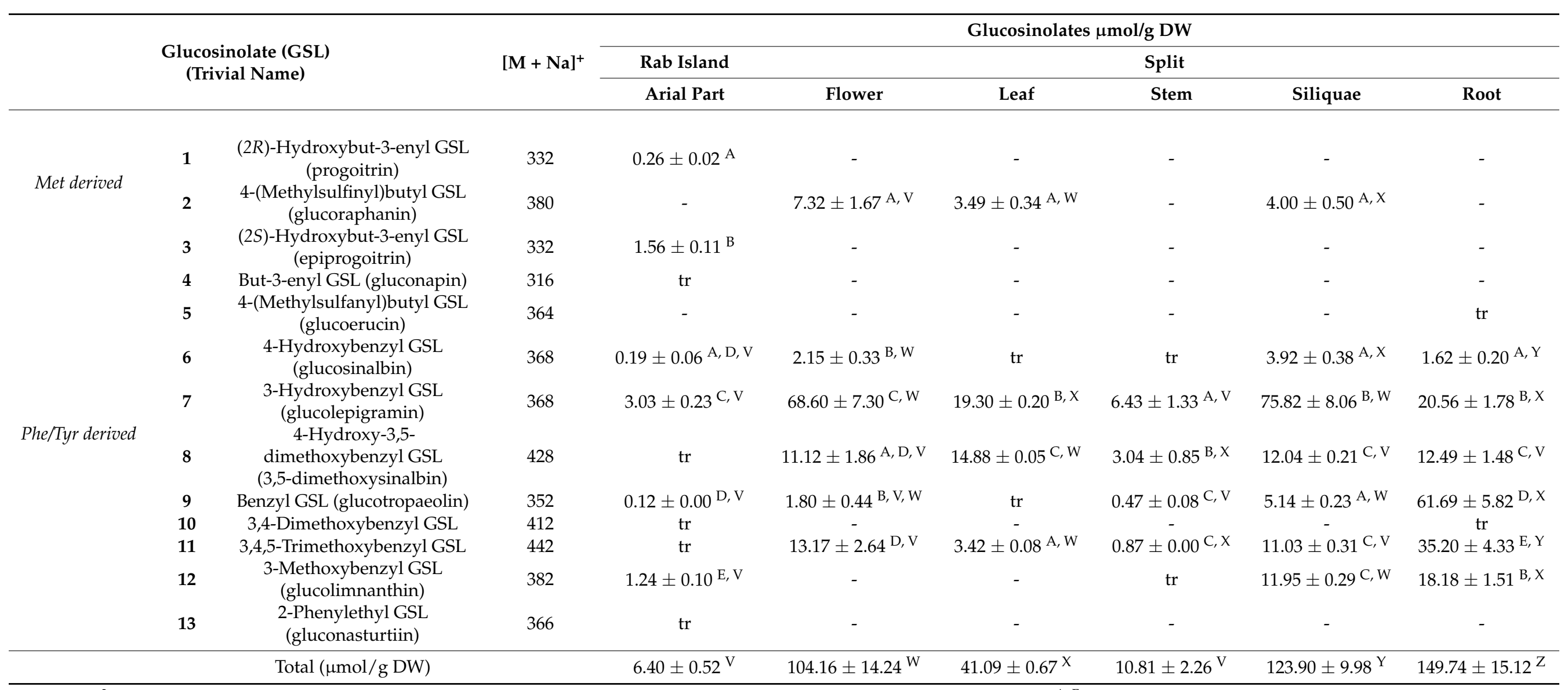

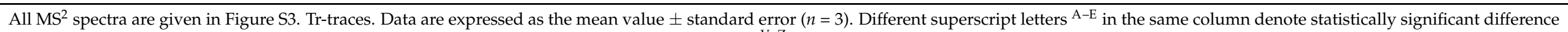

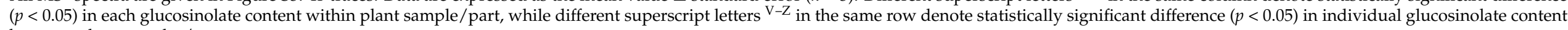
between plant samples/parts. 
<smiles>[R]/C(=N/OS(=O)(=O)O)S[C@H]1O[C@H](CO)[C@@H](O)[C@H](O)[C@H]1O</smiles>

Met derived<smiles>C=CCCC</smiles><smiles>C=CC(O)CC</smiles>

1<smiles>C=C[C@H](O)CC</smiles>

3

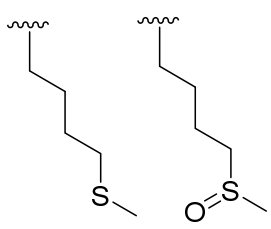

2
Phe/Tyr derived<smiles>[R3]c1cc(C[14CH3])cc([R])c1[R]</smiles>

6: $\mathrm{R}_{1}=\mathrm{R}_{3}=\mathrm{H} ; \mathrm{R}_{2}=\mathrm{OH}$

7: $\mathrm{R}_{1}=\mathrm{OH} ; \mathrm{R}_{2}=\mathrm{R}_{3}=\mathrm{H}$

8: $\mathrm{R}_{1}=\mathrm{R}_{3}=\mathrm{OCH}_{3} ; \mathrm{R}_{2}=\mathrm{OH}$

9: $\mathrm{R}_{1}=\mathrm{R}_{2}=\mathrm{R}_{3}=\mathrm{H}$

10: $\mathrm{R}_{1}=\mathrm{R}_{2}=\mathrm{OCH}_{3} ; \mathrm{R}_{3}=\mathrm{H}$

11: $\mathrm{R}_{1}=\mathrm{R}_{2}=\mathrm{R}_{3}=\mathrm{OCH}_{3}$

12: $\mathrm{R}_{1}=\mathrm{OCH}_{3} ; \mathrm{R}_{2}=\mathrm{R}_{3}=\mathrm{H}$

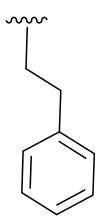

13

Figure 1. Structures of the GSLs identified in Lepidium graminifolium (cf. Table 1).

Table 2. Volatiles obtained from aerial parts of L. graminifolium using different methods of isolation.

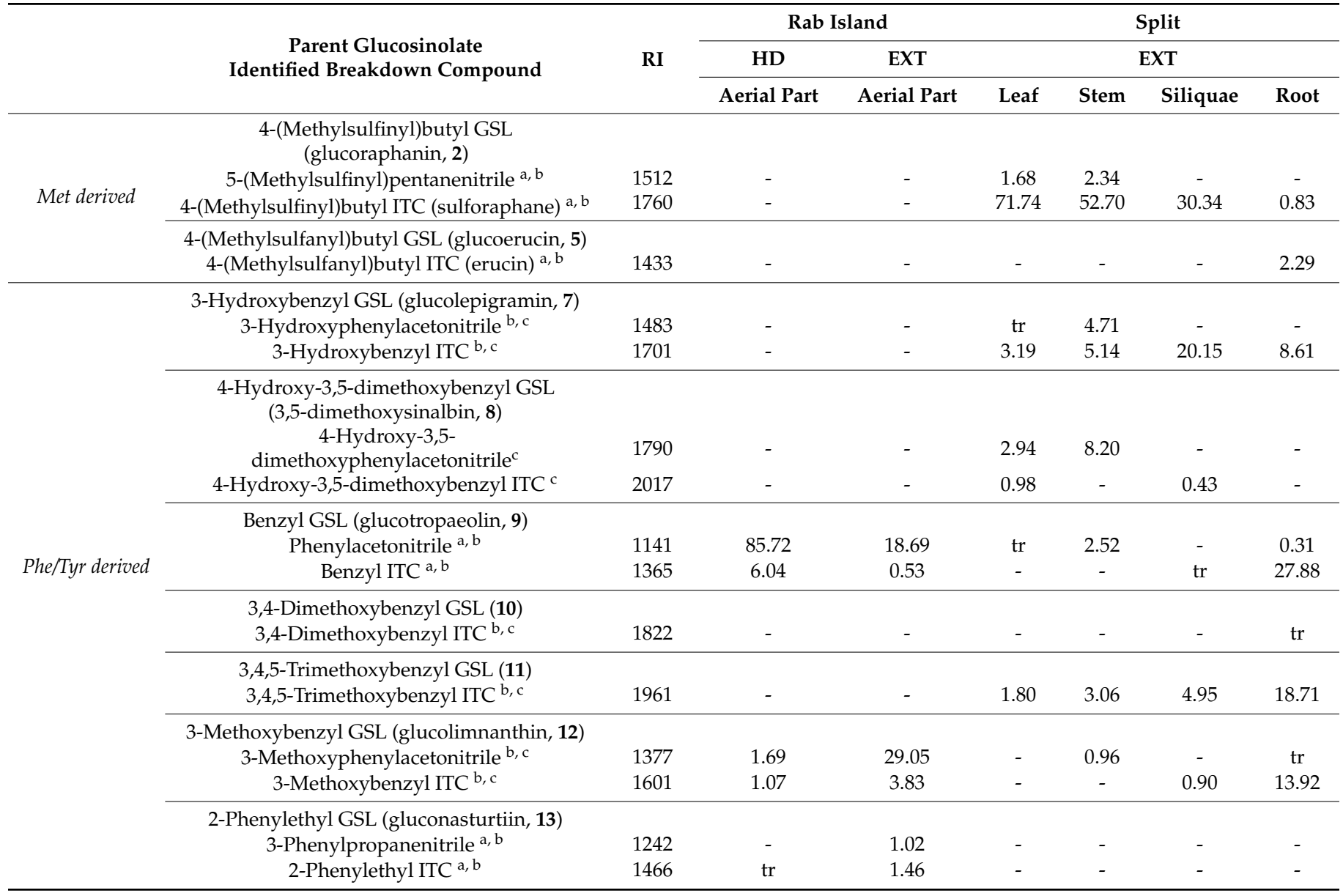


Table 2. Cont.

\begin{tabular}{|c|c|c|c|c|c|c|c|}
\hline \multirow{3}{*}{$\begin{array}{l}\text { Parent Glucosinolate } \\
\text { Identified Breakdown Compound }\end{array}$} & \multirow{3}{*}{ RI } & \multicolumn{2}{|c|}{ Rab Island } & \multirow{2}{*}{\multicolumn{4}{|c|}{$\begin{array}{l}\text { Split } \\
\text { EXT }\end{array}$}} \\
\hline & & \multirow{2}{*}{$\begin{array}{c}\text { HD } \\
\text { Aerial Part }\end{array}$} & \multirow{2}{*}{$\begin{array}{c}\text { EXT } \\
\text { Aerial Part }\end{array}$} & & & & \\
\hline & & & & Leaf & Stem & Siliquae & Root \\
\hline \multicolumn{8}{|l|}{ Other volatiles } \\
\hline Benzaldehyde ${ }^{a, b}$ & 963 & 1.97 & - & $\operatorname{tr}$ & 0.71 & 0.53 & 0.32 \\
\hline Benzyl alcohol a, b & 1036 & - & - & - & 0.96 & 0.80 & 0.58 \\
\hline 3-Methoxybenzaldehyde ${ }^{b}$ & 1198 & - & 4.57 & - & - & - & - \\
\hline 2-Methoxy-4-allylphenol (eugenol) a, b & 1358 & - & - & 1.60 & 8.28 & 8.04 & 5.48 \\
\hline$\beta$-Selinene $\mathrm{a}, \mathrm{b}$ & 1486 & - & 14.16 & - & - & - & - \\
\hline 4-Hydroxy-3,5-dimethoxybenzaldehyde ${ }^{b}$ & 1659 & - & - & 1.44 & 1.70 & - & $\operatorname{tr}$ \\
\hline Caffeine ${ }^{a, b}$ & 1839 & - & - & 7.96 & 8.20 & 30.55 & 18.71 \\
\hline 6,10,14-Trimethylpentadecan-2-one ${ }^{a, b}$ & 1846 & - & 17.46 & - & - & - & - \\
\hline Hexadecanoic acid $\mathrm{a}, \mathrm{b}$ & 1964 & - & 5.67 & - & - & - & - \\
\hline Ethylhexadecanoate ${ }^{a, b}$ & 1995 & - & 1.87 & - & - & - & - \\
\hline Total (\%) & & 96.49 & 98.31 & 93.33 & 99.48 & 96.69 & 97.64 \\
\hline
\end{tabular}

$\mathrm{HD}$, hydrodistillation in Clevenger-type apparatus; EXT, $\mathrm{CH}_{2} \mathrm{Cl}_{2}$ extraction after 24 h of autolysis and added myrosinase; $\mathrm{RI}$, retention indices determined on a HP-5MS UI capillary column; -, not detected; tr, traces; ITC, isothiocyanate. ${ }^{\text {a }}$ Compound identified by mass spectra and RI comparison with homemade library. ${ }^{b}$ Compound identified by mass spectra comparison with Wiley/NIST library. ${ }^{c}$ Compound identified by mass spectra comparison with literature values [4]. Spectra are given in Figure S4.

Generally, the dominant GSLs were from the arylaliphatic class, biosynthetically originating from Phe/Tyr. In total, eight arylaliphatic GSLs were identified as un-, mono, di- and tri- substituted ones. In plants, benzyl GSL (9) sometimes co-occurs with 4hydroxybenzyl GSL (6) [17,18], suggesting that the biosynthesis may in some cases originate from Phe only, with the hydroxyl group added as a secondary modification [1]. The most abundant peak in all samples analyzed (except root) was observed at $t_{R}=5.12 \mathrm{~min}$ with characteristic desulfo-GSL sodium adduct $m / z=368$ (Figures S2 and S3). It was identified as 3-hydroxybenzyl GSL (glucolepigramin) (7), with quantity ranging from 3.03 to $75.82 \mu \mathrm{mol} / \mathrm{g}$ of DW (Table 1, Figure 1). The corresponding breakdown products, 3-methoxybenzyl ITC and 3-methoxyphenylacetonitrile, were also detected by GC-MS (Table 2). The major GSL in the root from the Split sample was benzyl GSL (9), followed by 3,4,5-trimethoxybenzyl GSL (11) and 7, with $61.69,35.20$ and $20.56 \mu \mathrm{mol} / \mathrm{g}$ of DW, respectively. Highly substituted arylaliphatic GSLs are usually restricted to a few genera (e.g., Matthiola, Lepidium) [5,16]. To our knowledge, however, $\mathbf{1 1}$ was reported only in Lepidium species: L. hyssopifolium Desv., L. coronopus (L.) Al-Shebbaz, L. sordidum A. Gray, and L. densiflorum Schrad. $[4,5,15,17,19,20]$. Thus, $\mathbf{1 1}$ can be suggested as an important chemotaxonomic marker of Lepidium spp. Based on the identification of the rare GSL 11 in L. coronopus (syn. Coronopus squamatus (Forrsk.) Asch.), Radulović et al. even proposed a change of nomenclature of genus Coronopus to genus Lepidium [21]. In all Split samples, an abundant peak, observed at $t_{R}=5.59 \mathrm{~min}$, showed a characteristic desulfo-GSL sodium adduct $m / z=428$, which was identified as 4-hydroxy-3,5-dimethoxybenzyl GSL 8 (Table 1, Figures S2 and S3), with 3.04-14.88 $\mu \mathrm{mol} / \mathrm{g}$ of DW. Additionally, the breakdown products, 4-hydroxy-3,5-dimethoxyphenylacetonitrile and 4-hydroxy-3,5-dimethoxybenzyl ITC were identified by GC-MS (Table 2, Figure S4). GSL 8 was previously reported only in L. densiflorum [4].

Five minor GSLs 1-5 biosynthetically originate from Met. 1, 3 and 4 were found only in the sample collected from Rab Island, while they were absent in Split samples. They were also present in all parts (inflorescence, stem, root, fruit) reported previously [11]. On the other hand, 2 was present only in Split samples in all parts analyzed by their desulfo-GSL and/or its breakdown product 4-(methylsulfinyl)butyl ITC (sulforaphane). Traces of 5 were found in Split root sample only (Tables 1 and 2). According to the studies of biosynthetic route in the plant model Arabidopsis thaliana, Met-derived GSLs start with eight enzymatic steps in order to elongate the chain by two $\mathrm{C}$ atoms, followed by core GSL biosynthesis leading to the parent dihomoMet derived GSL, 4-(methylsulfanyl)butyl GSL (5). Further 
sequential secondary modifications of the parent GSL, via 4-(methylsulfinyl)butyl GSL (2) and but-3-enyl GSL (4) end with 2-hydroxybut-3-enyl GSL (mixture of two stereoisomers, 1 and 3) $[1,22]$. In our case the L. graminifolium collected in June 2021 (when it starts growing) contained $\mathbf{2}$ and 5, while samples collected in October 2016 contained $\mathbf{1}$ and $\mathbf{3}$ with traces of 4, indicating that the time of harvest may display a snapshot of a different step of the GSL biosynthetic pathway in the plant.

Other volatiles included 4-hydroxy-3,5-dimethoxybenzaldehyde and 3-methoxybenzal dehyde, which can be formed due to the instability of the corresponding ITCs during the isolation and/or GC conditions. 4-Hydroxy-3,5-dimethoxybenzaldehyde can be converted from 4-hydroxy-3,5-dimethoxybenzyl alcohol due to the presence of the electron-donating $\mathrm{OH}$ group in para position (Figure 2).

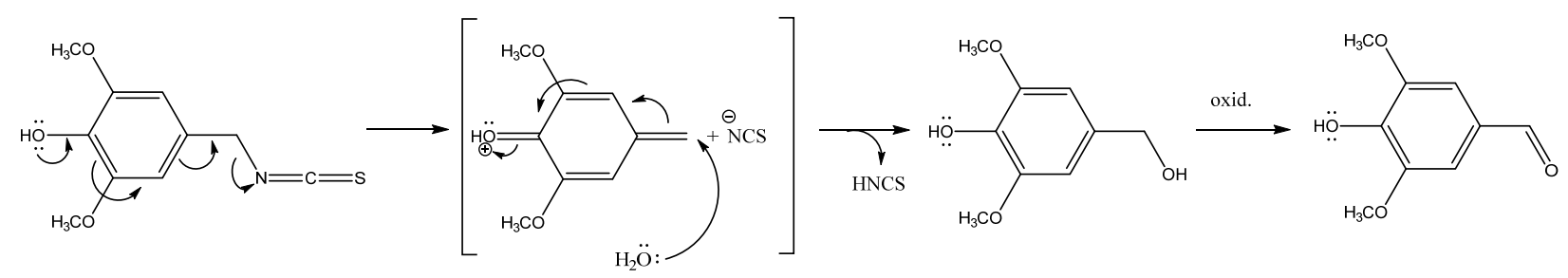

Figure 2. Proposed pathway for the conversion of 4-hydroxy-3,5-dimethoxybenzyl isothiocyanate into the corresponding aldehyde.

\subsection{Antiproliferative Activity}

The antiproliferative activity of volatile isolates obtained from Rab Island L. graminifolium was tested against human bladder cancer cell line UM-UC-3 and human glioblastoma cell line LN229 (Figure 3) using MTT assay and IC 50 values were calculated.
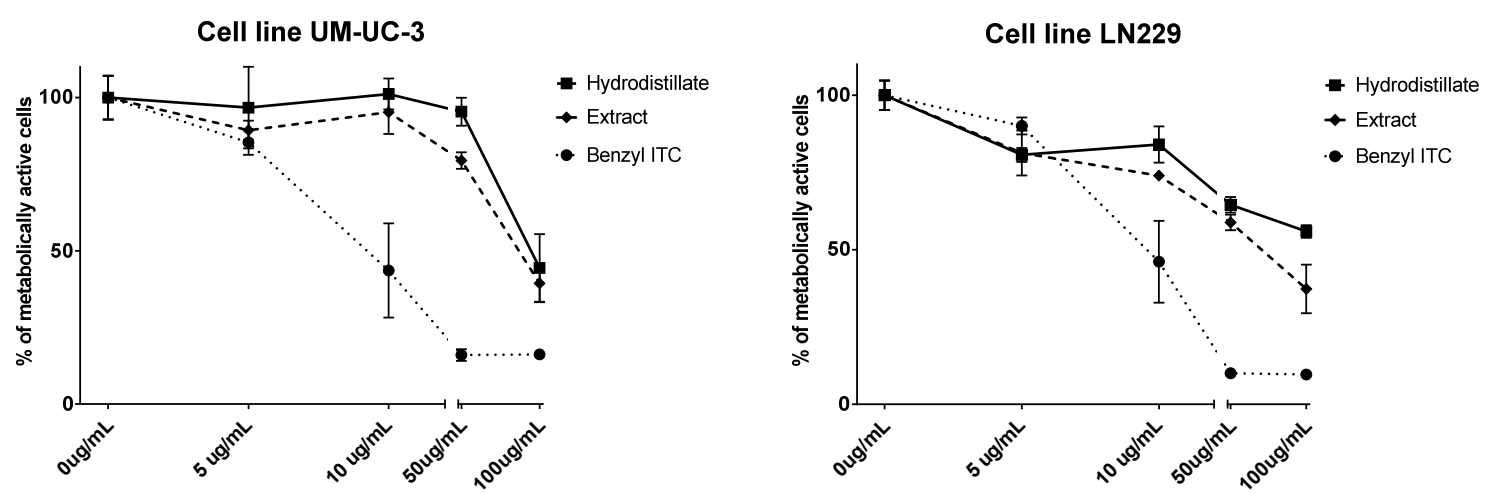

Figure 3. Percentage of metabolically active human bladder cancer cell line UM-UC-3 and human glioblastoma cell line LN229 after $72 \mathrm{~h}$ for different concentrations of L. graminifolium hydrodistillate, and extract as well as benzyl ITC.

According to the $\mathrm{IC}_{50}$ values, the antiproliferative activities of hydrodistillate and extract against UM-UC-3 cells after $72 \mathrm{~h}$ were ca. $100 \mu \mathrm{g} / \mathrm{mL}$, which can be considered as moderately active. $\mathrm{IC}_{50}$ of benzyl ITC was $12.3 \mu \mathrm{g} / \mathrm{mL}$, which can be considered as highly active. Based on the GC-MS analysis, it can be suggested that the formation of nitriles in HD (87.41\%), mostly phenylacetonitrile $(85.72 \%)$ from 9 (instead of benzyl ITC, $6.04 \%$ ), resulted in lower antiproliferative activities. Similarly, EXT contained high percentages of nitriles (48.76\%) in comparison to ITCs (5.82\%), mostly from 9 and $\mathbf{1 2}$ which suggested the same conclusion. However, regulation of cell proliferation, cell cycle, and apoptosis plays crucial roles in the ITC-induced anti-cancer effects, and such phenomena are mainly regulated by complex mechanisms involving caspases, Bcl-2 family proteins, and mitochondrial activities [23]. Benzyl ITC has shown antiproliferative and proapoptotic activity in bladder cells [24,25]. The treatment of UM-UC-3 cells with benzyl ITC and phenylethyl ITC at low micromolar concentrations caused the damage of both 
outer and inner mitochondrial membranes, leading to the release of cytochrome $c$ into the cytoplasm and caspase- 9 activation as the major step leading to induction of apoptosis in this cell line [24]. Additionally, benzyl ITC mitochondrial damage is regulated by various members of the Bcl-2 family, including Bcl-2, Bax, Bak, and Bcl-xl [24]. Moreover, Tang et al. found that the urinary $N$-acetylcysteine conjugate of benzyl ITC suppressed different bladder cancer cells' (RT4, UM-UC-6, UM-UC-6/dox) growth through antiproliferative and proapoptotic activities. The antiproliferative mechanisms of benzyl ITC and its $N$ acetylcysteine conjugate were identical, but relatively longer treatment time or slightly higher doses were needed for the latter compound to exert the same effect [25].

The activity of the extracts against tested LN229 cell line observed in the same time period was similar to the one against UM-UC-3, while HD showed lower activity (Figure 3). The $\mathrm{IC}_{50}$ of benzyl ITC was the same as against UM-UC-3 cells, i.e., $12.3 \mu \mathrm{g} / \mathrm{mL}$, which can be considered as highly active. The activity of benzyl ITC against LN229 was not previously studied, as far as the authors know [26]. Zhu et al. reported that benzyl ITC can inhibit proliferation of human glioma U87MG cells, induce apoptosis and cell cycle arrest of U87MG cells, the mechanism of which may be related to the fact that benzyl ITC can cause oxidative stress to tumor cells [27]. Tang et al. reported that benzyl ITC induced cytotoxic effects through the cell cycle arrest and affected cell cycle-associated gene expression and the induction of cell apoptosis in GBM 8401 cells in vitro [28], while Shang et al. reported benzyl ITC to induce apoptosis of GBM 8401 cells via activation of caspase-8/Bid and the reactive oxygen species-dependent mitochondrial pathway [29]. Phenylethyl ITC, structural analogue of benzyl ITC, was found to inhibit the growth of LN229 cells. It was shown that this ITC can arrest the cell cycle at phase G2/M. Furthermore, it was observed that it can raise ROS expression in the tumor cells, thus suggesting that it can activate caspase- 3 activity by affecting the cell cycle and inhibiting the superoxide dismutase activity as well as the glutathione expression [30].

\section{Materials and Methods}

\subsection{Materials and Reagents}

Lepidium graminifolium L. samples were obtained from wild-growing plants collected from two locations: Rab Island $\left(43^{\circ} 30^{\prime} 41.8^{\prime \prime} \mathrm{N}, 16^{\circ} 28^{\prime} 02.7^{\prime \prime} \mathrm{E}\right.$; October, 2016) and Split $\left(44^{\circ} 43^{\prime} 53.8^{\prime \prime} \mathrm{N}, 14^{\circ} 50^{\prime} 27.9^{\prime \prime} \mathrm{E}\right.$; June 2021$)$. The botanical identity of the plant material was confirmed by a local botanist, Dr. Mirko Ruščić, from the Faculty of Natural Sciences, University of Split, Croatia and stored under voucher numbers HCPMFST 2030 (old v.n. DBLG001) for Rab sample and HCPMFST 4350 for Split sample. Myrosinase, benzyl ITC and sinigrin were obtained from Sigma Aldrich (St. Louis, MO, USA). All other chemicals and reagents were of analytical grade. Cancer cell lines (human bladder cancer cell line UM-UC-3 and human glioblastoma cell line LN229) were cultured in a humidified atmosphere with $5 \% \mathrm{CO}_{2}$ at $37{ }^{\circ} \mathrm{C}$, in Dulbecco's modified Eagle medium (DMEM, EuroClone, Milan, Italy) containing $4.5 \mathrm{~g} / \mathrm{L}$ glucose, $10 \%$ fetal bovine serum (FBS) and 1\% antibiotics (penicillin streptomycin, EuroClone, Milan, Italy).

\subsection{Isolation and Chemical Analysis \\ 3.2.1. Isolation of Desulfoglucosinolates}

GSLs were extracted as previously reported [31,32]. The dried plant parts of Rab sample (aerial part) and Split sample (flower, leaf, stem, siliquae, root) were ground to a fine powder, from which $100 \mathrm{mg}$ were extracted for $5 \mathrm{~min}$ at $80^{\circ} \mathrm{C}$ in $2 \times 1 \mathrm{~mL} \mathrm{MeOH} / \mathrm{H}_{2} \mathrm{O}$ $(70: 30 \mathrm{v} / \mathrm{v})$ to inactivate the endogenous myrosinase. Each extract $(1 \mathrm{~mL})$ was loaded onto a mini-column filled with $0.5 \mathrm{~mL}$ of DEAE-Sephadex A-25 anion-exchange resin (GE Healthcare, Chicago, IL, USA) conditioned with $25 \mathrm{mM}$ acetate buffer ( $\mathrm{pH}$ 5.6). After washing the column with $70 \% \mathrm{MeOH}$ and $1 \mathrm{~mL}$ of ultrapure water, optimal conditions for desulfation were set by adding buffer solution. Each mini-column was loaded with $20 \mu \mathrm{L}$ $(0.35 \mathrm{U} / \mathrm{mL})$ of purified sulfatase and left to stand $18 \mathrm{~h}$ at room temperature. The desulfo- 
GSLs were then eluted with $1.5 \mathrm{~mL}$ of ultra-pure $\mathrm{H}_{2} \mathrm{O}$, lyophilized and diluted to the $1 \mathrm{~mL}$. The samples were stored at $-20{ }^{\circ} \mathrm{C}$ until further analysis by UHPLC-DAD-MS/MS.

\subsubsection{UHPLC-DAD-MS/MS Analysis}

Analysis was performed on UHPLC-DAD-MS/MS (Ultimate 3000RS with TSQ Quantis MS/MS detector, Thermo Fischer Scientific, Waltham, MA, USA) using Hypersil GOLD column $(3.0 \mu \mathrm{m}, 3.0 \times 100 \mathrm{~mm}$, Thermo Fischer Scientific). A gradient consisting of solvent A $\left(50 \mu \mathrm{M} \mathrm{NaCl}\right.$ in $\left.\mathrm{H}_{2} \mathrm{O}\right)$ and solvent $\mathrm{B}$ (acetonitrile: $\left.\mathrm{H}_{2} \mathrm{O} 30: 70 v / v\right)$ was applied at a flow rate of $0.5 \mathrm{~mL} / \mathrm{min}$ as follows: $0.14 \mathrm{~min} 96 \% \mathrm{~A}$ and $4 \% \mathrm{~B} ; 7.84 \mathrm{~min} 14 \% \mathrm{~A}$ and $86 \% \mathrm{~B}$; $8.96 \mathrm{~min} 14 \% \mathrm{~A}$ and $86 \% \mathrm{~B} ; 9.52 \mathrm{~min} 5 \% \mathrm{~A}$ and $95 \% \mathrm{~B} ; 13.16 \mathrm{~min} 5 \% \mathrm{~A}$ and $95 \% \mathrm{~B} ; 13.44 \mathrm{~min}$ $96 \% \mathrm{~A}$ and $4 \% \mathrm{~B} ; 15.68 \mathrm{~min} 96 \% \mathrm{~A}$ and $4 \% \mathrm{~B}$. The column temperature was held at $25{ }^{\circ} \mathrm{C}$ and the injection volume was $5 \mu \mathrm{L}$. The electrospray interface was H-ESI source operating with a capillary voltage of $3.5 \mathrm{kV}$ at $350{ }^{\circ} \mathrm{C}$. The system was operated in the positive ion electrospray mode.

The amount of GSLs was quantified using a calibration curve $(y=0.0206 x+0.2371$, $\mathrm{R}^{2}=0.9992, \mathrm{LOD}=1.67 \mu \mathrm{M}, \mathrm{LOQ}=5.03 \mu \mathrm{M}$ ) of pure desulfosinigrin solution (range from 13.63 to $545.00 \mu \mathrm{M}$ ) and RPFs for each individual desulfo-GSL [33]. RPF values for quantification of desulfo-GSLs were as follows: RPF 1.09 for $\mathbf{1}$ and 3, 1.07 for 2, 1.11 for $\mathbf{4}$, 1.04 for 5, 0.50 for 6, 0.95 for 9 and 13 [34]; RPF 0.55 for 12 [7]; arbitrary RPF 1.0 for 7, 8, 10 and 11.

\subsubsection{Isolation of Volatiles}

The volatiles from the Rab sample (aerial part) were isolated by two approaches. Hydrodistillation was performed in Clevenger-type apparatus for $2.5 \mathrm{~h}$ using $50 \mathrm{~g}$ of dry material (HD). Dry plant material (10 g) was ground (in a coffee grinder), stirred with $20 \mathrm{~mL}$ of distilled water, and after endogenous and exogenous hydrolysis by myrosinase (1-2 units) for $24 \mathrm{~h}$ at $27^{\circ} \mathrm{C}$ and $\mathrm{pH} 5.4$, was extracted using $\mathrm{CH}_{2} \mathrm{Cl}_{2}$ (EXT). pH was determined using a $\mathrm{pH}$ meter (Hanna Instruments, Woonsocket, RI, USA). The Split samples (flower, leaf, stem, silliquae, root) were extracted using $1 \mathrm{~g}$ of each plant part (EXT) $[31,32]$.

\subsubsection{GC-MS Analysis}

The gas chromatography system used consisted of gas chromatograph, model 8890 GC, equipped with an automatic liquid injector, model 7693A, and tandem mass spectrometer (MS/MS), model 7000D GC/TQ (Agilent Inc., Santa Clara, CA, USA). The samples were analyzed on a non-polar HP-5MS UI column (dimensions: $30 \mathrm{~m}$ length, inner diameter $0.25 \mathrm{~mm}$ and stationary phase layer thickness $0.25 \mu \mathrm{m}$, Agilent Inc., Santa Clara, CA, USA). The column temperature program was set at $60^{\circ} \mathrm{C}$ for the first $3 \mathrm{~min}$ and then heated to $246^{\circ} \mathrm{C}$ at $3{ }^{\circ} \mathrm{C} / \mathrm{min}$, and maintained for $25 \mathrm{~min}$ isothermally. The carrier gas was helium, and the flow rate was $1 \mathrm{~mL} / \mathrm{min}$. The inlet temperature was $250^{\circ} \mathrm{C}$, while the volume of the injected sample was $1 \mu \mathrm{L}$. Other conditions were as follows: ionization energy was $70 \mathrm{eV}$; ion source temperature was $230^{\circ} \mathrm{C}$; the temperature of the quadrupoles was set at $150{ }^{\circ} \mathrm{C}$. The analyses were carried out in duplicate.

The individual peaks were identified by comparison of their retention indices (relative to $\mathrm{C}_{8}-\mathrm{C}_{40} n$-alkanes for HP-5MS UI column) to those from a homemade library, literature and/or authentic samples, as well as by comparing their mass spectra with literature, Wiley 9N08 MS (Wiley, New York, NY, USA) and NIST17 (Gaithersburg, MD, USA) mass spectral databases. The percentages in Table 2 were calculated as the mean value of component percentages on HP-5MS UI column for analyses run in duplicate.

\subsection{Cell Viability Assay (MTT)}

MTT spectrophotometric assay was performed on a microplate photometer, model HiPo MPP-96 (BioSan, Riga, Latvia) as previously described [19,20]. The criteria used to categorize the activity against the tested cell lines were based on $\mathrm{IC}_{50}$ values as follows: 
$20 \mu \mathrm{g} / \mathrm{mL}=$ highly active, $21-200 \mu \mathrm{g} / \mathrm{mL}=$ moderately active, $201-500 \mu \mathrm{g} / \mathrm{mL}=$ weakly active, and $>501 \mu \mathrm{g} / \mathrm{mL}=$ inactive [35]. Thus, the cells were treated with Rab L. graminifolium volatile isolates (HD, EXT) at concentrations of 5, 10, 50 and $100 \mu \mathrm{g} / \mathrm{mL}$ in a complete medium (in triplicate) for $72 \mathrm{~h}$. After treatment with isolated compounds, the cells were incubated with $0.5 \mathrm{~g}$ MTT $/ \mathrm{L}$ at $37^{\circ} \mathrm{C}$ for $2 \mathrm{~h}$, the medium was removed, then DMSO was added, and the mixture was incubated for another $10 \mathrm{~min}$ at $37^{\circ} \mathrm{C}$ while shaking. The degree of formazan formation, an indicator of living and metabolically active cells, was measured at $570 \mathrm{~nm}$. The data were calculated in relation to the untreated control $(100 \%)$ from three independent measurements. The calculation of $\mathrm{IC}_{50}$ values was performed using GraphPad Prism software version 7.0.

\subsection{Statistical Analysis}

Analysis of variance (one-way ANOVA) was used to assess the statistical difference between data reported in Table 1 , followed by a least significance difference test to evaluate differences between sets of mean values at significance level set at $p<0.05$. Analyses were carried out using Statgraphics Centurion-Ver.16.1.11 (StatPoint Technologies, Inc., Warrenton, VA, USA) [36].

\section{Conclusions}

GSLs in L. graminifolium were quantified for the first time by UHPLC-DAD-MS/MS. In addition, new GSLs were identified in this species: glucoraphanin (2), glucoerucin (5) and one multi-substituted benzyl GSL, 4-hydroxy-3,5-dimethoxybenzyl GSL (8), which was previously reported only in L. densiflorum. Multi-substituted benzyl GSLs, such as 3,4,5-trimethoxybenzyl GSL, are rarely found but seem to be common for Lepidium species. Generally, the biosynthetic pathways are still poorly investigated, especially in most nonmodel plants, and they should be the focus of further studies. Antiproliferative effects of the tested volatile isolates rich in GSL breakdown products (mostly nitriles) on cancer cells showed moderate potential, while benzyl ITC showed high potential. Thus, different factors influencing the formation of GSL breakdown products can consequently lead to better activity of isolates containing ITCs. In addition, further experiments on benzylic-type ITCs should be performed to clarify the antiproliferative effects and underlying mechanisms.

Supplementary Materials: The following are available online. Figure S1. Chromatogram of desulfoGSLs obtained from the aerial parts of L. graminifolium from Rab Island: d1-(2R)-Hydroxybut-3enyl GSL (progoitrin), d3-(2S)-Hydroxybut-3-enyl GSL (epiprogoitrin), d4-But-3-enyl GSL (gluconapin), d6-4-Hydroxybenzyl GSL (glucosinalbin), d7-3-Hydroxybenzyl GSL (glucolepigramin), d8-4-Hydroxy-3,5-dimethoxybenzyl GSL (3,5-dimethoxysinalbin), d9-Benzyl GSL (glucotropaeolin), d10-3,4-Dimethoxybenzyl GSL, d11-3,4,5-Trimethoxybenzyl GSL, d12-3-Methoxybenzyl GSL (glucolimnanthin), d13-2-Phenylethyl GSL (gluconasturtiin).; Figure S2. Chromatogram of desulfo-GSLs obtained from the leaf, siliquae, flower, stem and root of L. graminifolium from Split: d2-(2S)-Hydroxybut3-enyl GSL (glucoraphanin), d5-4-(Methylsulfanyl)butyl GSL (glucoerucin), d6-4-Hydroxybenzyl GSL (glucosinalbin), d7-3-Hydroxybenzyl GSL (glucolepigramin), d8-4-Hydroxy-3,5-dimethoxybenzyl GSL (3,5-dimethoxysinalbin), d9-Benzyl GSL (glucotropaeolin), d10-3,4-Dimethoxybenzyl GSL, d113,4,5-Trimethoxybenzyl GSL, d12-3-Methoxybenzyl GSL (glucolimnanthin).; Figure S3. MS ${ }^{2}$ spectra at $15 \mathrm{~V}$ ionization of desulfo-GLSs detected: d1- d13.; Figure S4. MS spectra of degradation products originating from substituted benzylic-type GSLs. Numbers correspond to Table 1 and Figure 1.

Author Contributions: Chemistry investigation: A.Đ., F.B., P.B., S.M., P.R. and I.B.; Cell culture and cytotoxic assays: V.Č.Č; Plant collection and botanical identification: M.R.; Writing-original draft: I.B.; Writing - review and editing: all authors. All authors have read and agreed to the published version of the manuscript.

Funding: This research has been fully supported by the Croatian Science Foundation (Grant IP-2016-06-1316).

Institutional Review Board Statement: Not applicable.

Informed Consent Statement: Not applicable. 
Acknowledgments: We are also thankful for the scientific-research equipment financed by EU grant KK.01.1.1.02.0018.

Conflicts of Interest: The authors declare that they have no conflict of interest.

\section{References}

1. Blažević, I.; Montaut, S.; Burčul, F.; Olsen, C.E.; Burow, M.; Rollin, P.; Agerbirk, N. Glucosinolate structural diversity, identification, chemical synthesis and metabolism in plants. Phytochemistry 2020, 169, 112100. [CrossRef]

2. Montaut, S.; Read, S.; Blažević, I.; Nuzillard, J.-M.; Roje, M.; Harakat, D.; Rollin, P. Investigation of the glucosinolates in Hesperis matronalis L. and Hesperis laciniata All.: Unveiling 4'-O- $\beta$-D-apiofuranosylglucomatronalin. Carbohydr. Res. 2020, $488,107898$. [CrossRef] [PubMed]

3. Trabelcy, B.; Chinkov, N.; Samuni-Blank, M.; Merav, M.; Izhaki, I.; Carmeli, S.; Gerchman, Y. Investigation of glucosinolates in the desert plant Ochradenus baccatus (Brassicales: Resedaceae). Unveiling glucoochradenin, a new arabinosylated glucosinolate. Phytochemistry 2021, 187, 112760. [CrossRef]

4. Pagnotta, E.; Agerbirk, N.; Olsen, C.E.; Ugolini, L.; Cinti, S.; Lazzeri, L. Hydroxyl and methoxyl derivatives of benzylglucosinolate in Lepidium densiflorum with hydrolysis to isothiocyanates and non-isothiocyanate products: Substitution governs product type and mass spectral fragmentation. J. Agric. Food Chem. 2017, 65, 3167-3178. [CrossRef]

5. Blažević, I.; Montaut, S.; Burčul, F.; Rollin, P. Glucosinolates: Novel sources and biological potential. In Glucosinolates, Reference Series in Phytochemistry; Mérillon, J.-M., Ramawat, K.G., Eds.; Springer: Cham, Switzerland, 2017; pp. 3-60. [CrossRef]

6. Radulović, N.S.; Dekić, M.S.; Stojanović-Radić, Z.Z. Antimicrobial volatile glucosinolate autolysis products from Hornungia petraea (L.) Rchb. (Brassicaceae). Phytochem. Lett. 2012, 5, 351-357. [CrossRef]

7. De Nicola, G.R.; Nyegue, M.; Montaut, S.; Iori, R.; Menut, C.; Tatibouët, A.; Rollin, P.; Ndoyé, C.; Zollo, P.-H.A. Profile and quantification of glucosinolates in Pentadiplandra brazzeana Baillon. Phytochemistry 2012, 73, 51-56. [CrossRef] [PubMed]

8. Blažević, I.; Đulović, A.; Čikeš Čulić, V.; Burčul, F.; Ljubenkov, I.; Ruščić, M.; Generalić Mekinić, I. Bunias erucago L.: Glucosinolate profile and in vitro biological potential. Molecules 2019, 24, 741. [CrossRef]

9. De Nicola, G.R.; Montaut, S.; Rollin, P.; Nyegue, M.; Menut, C.; Iori, R.; Tatibouët, A. Stability of benzylic-type isothiocyanates in hydrodistillation-mimicking conditions. J. Agric. Food Chem. 2013, 61, 137-142. [CrossRef]

10. Nikolić, T. (2005-Onwards): Flora Croatica Database. Available online: http://hirc.botanic.hr/fcd (accessed on 14 August 2021).

11. Stevens, P.F. Angiosperm Phylogeny Website.Version 14. Available online: http://www.mobot.org/MOBOT/research/APweb/ (accessed on 22 July 2021).

12. Friis, P.; Kjær, A. Glucolepigramin, a new thioglucoside, present in Lepidium graminifolium L. Acta Chem. Scand. 1963, 17, 1515-1520. [CrossRef]

13. Bäuerle, R.; Wagner, H.; Schraudolf, H. Distribution of 4-methoxy-3-indolylmethyl-glucosinolate (4-methoxy-glucobrassicin) in Brassicaceae. Experientia 1986, 42, 86. [CrossRef]

14. Cole, R.A. Isothiocyanates, nitriles and thiocyanates as products of autolysis of glucosinolates in Cruciferae. Phytochemistry 1976, 15, 759-762. [CrossRef]

15. Daxenbichler, M.E.; Spencer, G.F.; Carlson, D.G.; Rose, G.B.; Brinker, A.M.; Powell, R.G. Glucosinolate composition of seeds from 297 species of wild plants. Phytochemistry 1991, 30, 2623. [CrossRef]

16. Montaut, S.; Read, S.; Blažević, I.; Nuzillard, J.-M.; Harakat, D.; Rollin, P. Glucosinolates of Lepidium graminifolium L. (Brassicaceae) from Croatia. Nat. Prod. Res. 2019, 33, 1-5. [CrossRef] [PubMed]

17. Bennett, R.N.; Mellon, F.A.; Kroon, P.A. Screening crucifer seeds as sources of specific intact glucosinolates using ion-pair high-performance liquid chromatography negative ion electrospray mass spectrometry. J. Agric. Food Chem. 2004, 52, 428-438. [CrossRef] [PubMed]

18. Agerbirk, N.; Warwick, S.I.; Hansen, P.R.; Olsen, C.E. Sinapis phylogeny and evolution of glucosinolates and specific nitrile degrading enzymes. Phytochemistry 2008, 69, 2937-2949. [CrossRef]

19. Kjær, A.; Schuster, A.; Park, R.J. Glucosinolates in Lepidium species from Queensland. Phytochemistry 1971, 10, 455. [CrossRef]

20. Kjær, A.; Wagnieres, M. 3,4,5-Trimethoxybenzylglucosinolate: A constituent of Lepidium sordidum. Phytochemistry 1971, 10, 2195. [CrossRef]

21. Radulović, N.; Zlatković, B.; Skropeta, D.; Palić, R. Chemotaxonomy of the peppergrass Lepidium coronopus (L.) Al-Shehbaz (syn. Coronopus squamatus) based on its volatile glucosinolate autolysis products. Biochem. Syst. Ecol. 2008, 36, 807-811. [CrossRef]

22. Sønderby, I.E.; Geu-Flores, F.; Halkier, B.A. Biosynthesis of glucosinolates-Gene discovery and beyond. Trends Plant. Sci. 2010, 15, 283-290. [CrossRef]

23. Mastuo, T.; Miyata, Y.; Yuno, T.; Mukae, Y.; Otsubo, A.; Mitsunari, K.; Ohba, K.; Sakai, H. Molecular mechanisms of the anti-cancer effects of isothiocyanates from cruciferous vegetables in bladder cancer. Molecules 2020, 25, 575. [CrossRef]

24. Tang, L.; Zhang, Y. Mitochondria are the primary target in isothiocyanate-induced apoptosis in human bladder cancer cells. Mol. Cancer. Ther. 2005, 4, 1250-1259. [CrossRef]

25. Tang, L.; Li, G.; Song, L.; Zhang, Y. The principal urinary metabolites of dietary isothiocyanates, $N$-acetylcysteine conjugates, elicit the same anti-proliferative response as their parent compounds in human bladder cancer cells. Anti-Cancer Drugs 2006, 17, 297-305. [CrossRef] 
26. Dinh, T.N.; Parat, M.-O.; Ong, Y.S.; Khaw, K.Y. Anticancer activities of dietary benzyl isothiocyanate: A comprehensive review. Pharmacol. Res. 2021, 169, 105666. [CrossRef] [PubMed]

27. Zhu, Y.; Zhuang, J.-X.; Wang, Q.; Zhang, H.-Y.; Yang, P. Inhibitory effect of benzyl isothiocyanate on proliferation in vitro of human glioma cells. Asian Pac. J. Cancer Prev. 2013, 14, 2607-2610. [CrossRef]

28. Tang, N.Y.; Chueh, F.S.; Yu, C.-C.; Liao, C.-L.; Lin, J.-J.; Hsia, T.-C.; Wu, K.-C.; Liu, H.-C.; Lu, K.-W.; Chung, J.-G. Benzyl isothiocyanate alters the gene expression with cell cycle regulation and cell death in human brain glioblastoma GBM 8401 cells. Oncol. Rep. 2016, 35, 2089-2096. [CrossRef]

29. Shang, H.-S.; Shih, Y.-L.; Lu, T.-J.; Lee, C.-H.; Hsueh, S.-C.; Chou, Y.-C.; Lu, H.-F.; Liao, N.-C.; Chung, J.-G. Benzyl isothiocyanate (BITC) induces apoptosis of GBM 8401 human brain glioblastoma multiforms cells via activation of caspase-8/bid and the reactive oxygen species-dependent mitochondrial pathway. Environ. Toxicol. 2016, 31, 1751-1760. [CrossRef] [PubMed]

30. Su, J.-C.; Lin, K.; Wang, Y.; Sui, S.-H.; Gao, Z.-Y.; Wang, Z.-G. In vitro studies of phenethyl isothiocyanate against the growth of LN229 human glioma cells. Int. J. Clin. Exp. Pathol. 2015, 8, 4269-4276. [PubMed]

31. Blažević, I.; Đulović, A.; Čikeš Čulić, V.; Popović, M.; Guillot, X.; Burčul, F.; Rollin, P. Microwave-assisted versus conventional isolation of glucosinolate degradation products from Lunaria annua L. and their cytotoxic activity. Biomolecules 2020, 10, 215. [CrossRef] [PubMed]

32. Popović, M.; Maravić, A.; Čikeš Čulić, V.; Đulović, A.; Burčul, F.; Blažević, I. Biological effects of glucosinolate degradation products from horseradish: A horse that wins the race. Biomolecules 2020, 10, 343. [CrossRef]

33. Grosser, K.; van Dam, N.M.A. Straightforward method for glucosinolate extraction and analysis with high-pressure liquid chromatography (HPLC). J. Vis. Exp. 2017, 121, e55425. [CrossRef]

34. Wathelet, J.-P.; Iori, R.; Leoni, O.; Quinsac, A.; Palmieri, S.; Rollin, P. Guidelines for glucosinolate analysis in green tissues used for biofumigation. Agroindustria. 2004, 3, 257-344.

35. Al-Gendy, A.A.; Nematallah, K.A.; Zaghloul, S.S.; Ayoub, N.A. Glucosinolates profile, volatile constituents, antimicrobial, and cytotoxic activities of Lobularia libyca. Pharm. Biol. 2016, 54, 3257-3263. [CrossRef] [PubMed]

36. Šimat, V.; Vlahović, J.; Soldo, B.; Generalić Mekinić, I.; Čagalj, M.; Hamed, I.; Skroza, D. Production and characterization of crude oils from seafood processing by-products. Food Biosci. 2020, 33, 100484. [CrossRef] 